\title{
Breeding against mycorrhizal symbiosis: modern cotton (Gossypium hirsutum L.) varieties perform more poorly than older varieties except at very high phosphorus supply
}

\section{Xinxin Wang}

China Agricultural University

Min Zhang

China Agricultural University

Jiandong Sheng

Xinjiang Agricultural University

Gu Feng ( $\sim$ fenggu@cau.edu.cn )

China Agricultural University https://orcid.org/0000-0002-1052-5009

Thomas W. Kuyper

Wageningen University \& Research

\section{Research Article}

Keywords: cotton varieties, plant breeding, phosphorus, arbuscular mycorrhizal fungi, root traits, root economics space, outsourcing, phosphorus acquisition

Posted Date: May 11th, 2021

DOl: https://doi.org/10.21203/rs.3.rs-510108/v1

License: (c) (i) This work is licensed under a Creative Commons Attribution 4.0 International License.

Read Full License 


\section{Abstract \\ Background and aims}

Cotton (Gossypium hirsutum L.) is an important cash fiber crop species, but its root traits related to phosphorus $(\mathrm{P})$ acquisition have been poorly understood.

\section{Methods}

Eight cotton varieties that were released between 1950 and 2013 were grown in pots with or without arbuscular mycorrhizal fungi (AMF) at three P supply levels. Eleven root traits were measured and calculated after seven weeks of growth.

\section{Results}

At the lower two $\mathrm{P}$ levels mycorrhizal plants acquired more $\mathrm{P}$ and produced more biomass than nonmycorrhizal plants. At the highest $\mathrm{P}$ level mycorrhizal plants took up more $\mathrm{P}$ than non-mycorrhizal plants, but there was no difference in biomass. At the intermediate $P$ level, root diameter was significantly positively correlated with biomass, $\mathrm{P}$ concentration and $\mathrm{P}$ content of mycorrhizal plants. More recent accessions had smaller root diameters, acquired less $\mathrm{P}$ and obtained less biomass, indicating (inadvertent) varietal selection for thinner roots that provided less cortical space for AMF, which increased the need for high $P$ fertilizer.

\section{Conclusion}

Our study provides support for the importance of the outsourcing model of nutrient acquisition in the root economics space framework. Inadvertent varietal selection in the last decades, resulting in thinner roots and a lower benefit from mycorrhizal colonization, has caused a lower productivity of cotton varieties at moderate P supply, indicating the need to rethink cotton breeding efforts in order to achieve agricultural sustainability.

\section{Introduction}

Phosphorus $(\mathrm{P})$ is an essential nutrient for plant growth, development and reproduction (Raghothama 1999). However, in many parts of the world $P$ deficiency is a major limiting factor for crop yield and hence is a major cause for food insecurity and constrained economic development. P-limitation can be addressed by application of synthetic P-fertilizer; however, due to strong sorption reactions of $\mathrm{P}$ with the soil mineral matrix (Zhang et al. 2008), P fertilizer supply does not always translate into larger yields (Vance et al. 2003). Different plant species and varieties have distinct strategies with different combinations of traits to respond to nutrient limitation (Lambers et al. 2006). These strategies have been 
captured in a conceptual model of the plant economics spectrum (Reich 2014) where plants are arranged in a one-dimensional spectrum from conservative to acquisitive plants. However, root traits did not fit easily in this one-dimensional framework. Recently, Bergmann et al. (2020) proposed a model for the root economics space, where root traits were classified along two dimensions. The first and most important dimension was called the collaboration gradient, where plants are classified ranging from a do-it-yourself strategy, with roots with a small diameter and high specific root length (SRL), to an outsourcing strategy, where nutrient acquisition is outsourced to mutualistic arbuscular mycorrhizal fungi (AMF). In order to accommodate these beneficial fungi, outsourcing plants have thick roots with a large cortical area and low SRL.

Root traits have an underlying genetic basis, next to showing environmental plasticity. Intraspecific variability in root traits has been shown for several crops including cereals and legumes (Fageria 2014; Fageria et al. 2016; Wang et al. 2020a), while genetic variation in the benefits that different plant varieties derive from the AMF symbiosis has been discussed by Kuyper et al. (2021). The ultimate goal of harnessing genetic variation in root traits, including traits related to the AMF symbiosis, is to select for root phenotypes that provide substantial benefits to plant growth at sustainable nutrient supply (Lynch 2019; Wang et al. 2020b). It is therefore important to screen crop varieties for $P$ acquisition efficiency and to link these efficiencies to root traits, including mycorrhizal traits (Bardgett et al. 2014), in order to select root traits that predict plant performance under conditions of variable P supply. Selecting root traits that are predictive for plant performance under varying conditions of supply, is an important strategy to improve yield at the same $P$ supply or to maintain yields at lower $P$ supply, considering that $P$ is a nonrenewable resource and excessive use of $P$ fertilizer has caused a number of environmental problems world-wide (Blaas and Kroeze 2016; Liu et al. 2008; Yan et al. 2013).

Currently, scientists are searching for specific traits or trait categories as the best indicator in screening programs. For herbaceous perennial legumes, Pang et al. (2015) observed that rhizosphere carboxylate content and rhizosphere acid phosphatase activity of two Australian pasture legumes were highly correlated with P-uptake at low availability of sparingly soluble P sources. Zhu and Lynch (2004) suggested that enhanced lateral rooting under P deficiency may be harnessed as a useful trait for the selection and breeding of more P-efficient maize genotypes. Other researchers have attempted to discover genetic loci that code for mycorrhizal responsiveness (Galván et al. 2011; Kaeppler et al. 2000). Although Kaeppler et al. (2000) suggested that mycorrhizal responsiveness could be harnessed to develop maize cultivars for $\mathrm{P}$ deficient regions to reduce $\mathrm{P}$ input, there is still insufficient consideration of AMF in crop breeding programs for enhanced $P$ acquisition efficiency (Sawers et al. 2008).

Studies provided evidence of trade-offs between beneficial root traits, suggesting that such traits cannot be stacked in one plant. Trade-offs suggest benefits of crop-specific root-trait-based management to cope with variable nutrient supply in agricultural production systems (Lyu et al. 2016). Trade-offs occur along the root collaboration gradient (Bergmann et al. 2020), where plants either invest in thinner roots, enlarging root surface per unit carbon, or thicker roots, enlarging space for AMF. Trade-offs between carboxylate production and mycorrhizal colonization have also been reported (Gao et al. 2007; Ryan et al. 
2012; Wen et al. 2019). Chu et al. (2013) found that morphological and physiological traits of maize roots mainly contributed to P uptake at low-P availability levels compared with mycorrhizal traits. In other studies, root morphological and physiological traits, and mycorrhizal traits have been shown to be equally important for $P$ acquisition, particularly in low-P soils (Hodge et al. 2009). Plant species relying more on root morphology depended less on rhizosphere carboxylates for $P$ acquisition (Kidd et al. 2015). Lyu et al. (2016) therefore suggested that plant species can be grouped on the basis of their response to soil $\mathrm{P}$ as either via root architectural or via exudation plasticity.

Cotton (Gossypium hirsutum L.), the main source of natural fiber worldwide, is an important cash crop in China, India, Pakistan and USA. It is often planted in semi-arid areas, where soils are low in P (Gill et al. 2005). In semi-arid areas, drought and salinity further adversely influence cotton growth. AMF may alleviate these various stresses (Eskandari et al. 2018; Kuyper et al. 2021). Cotton is poorly responsive to P-fertilizer application and lacks the ability to acquire $\mathrm{P}$ from sparingly soluble $\mathrm{P}$ sources (Wang et al. 2010), making it likely that cotton is crucially dependent on the AMF symbiosis. In agreement with this, Damodaran et al. (2012) noted for cotton cultivars a high mycorrhizal responsiveness. When testing different cotton varieties for $P$ acquisition efficiency in a hydroponic system, Chen et al. (2019) noted that at low $\mathrm{P}$ supply both fine-root ratio and specific root length were positively correlated with $\mathrm{P}$ acquisition efficiency, suggesting higher efficiency of varieties with thinner roots. It is not known how cotton breeding during the last decades has affected its ability to acquire P directly and via the AMF pathway.

We therefore conducted a pot experiment with eight cotton varieties released in different years (see M\&M section) at three levels of $\mathrm{P}$ supply. We conducted the experiment to address the role of (mycorrhizal) root traits and to explore the interplay of root and mycorrhizal traits in enhancing $\mathrm{P}$ acquisition. We addressed five questions: 1) have root traits of cotton varieties changed over time? 2) has mycorrhizal (P) responsiveness of cotton varieties changed over time? 3 ) how much do cotton varieties respond to AMF at different $\mathrm{P}$ levels; 4) can cotton varieties be bred for high productivity and high $\mathrm{P}$ uptake? 5 ) is it possible to come up with indicators that predict $P$ uptake and plant performance over a range of $P$ supplies, but at least at a sustainable $P$ supply?

\section{Materials And Methods}

\section{Experimental design}

Our experiment was a three-factorial experiment: cotton varieties (eight varieties) $\times \mathrm{P}$ supply (three levels: 0,50 , and $300 \mathrm{mg} \mathrm{P} \mathrm{kg}^{-1}$ soil) $\times$ mycorrhiza (two levels: with and without AMF). To pots (height, $15 \mathrm{~cm}$; diameter, $19 \mathrm{~cm}$ ) we added $2 \mathrm{~kg}$ soil. The experiment was conducted in a greenhouse at the China Agricultural University, Beijing ( $\left.40^{\circ} 01^{\prime} 267^{\prime \prime} \mathrm{N}, 116^{\circ} 16^{\prime} 36^{\prime \prime} \mathrm{E}\right)$. The glasshouse temperature range was 25-30 ${ }^{\circ} \mathrm{C}$ (day/night), and average photosynthetically actively radiation was $380 \mu \mathrm{mol} \mathrm{m} \mathrm{m}^{-2} \mathrm{~s}^{-1}$. There was no supplementary lighting. There were four replicates for each treatment, giving 192 pots in total. The pots were arranged in randomized blocks in the greenhouse, and the position of each block was re-randomized weekly. 
A calcareous loamy soil was collected from field plots at the Changping Long-Term Fertilizer Station of China Agricultural University in Beijing, China $\left(40^{\circ} 05^{\prime} 32^{\prime \prime} \mathrm{N}, 116^{\circ} 20^{\prime} 41^{\prime \prime} \mathrm{E}\right)$. The soil contained $17.8 \mathrm{~g} \mathrm{~kg}^{-1}$ organic matter, $2.9 \mathrm{mg} \mathrm{kg}^{-1}$ Olsen-P, $872 \mathrm{mg} \mathrm{kg}^{-1} \mathrm{~N}(\mathrm{C}: \mathrm{N} \approx 10), 156 \mathrm{mg} \mathrm{kg}^{-1}$ ammonium acetateexchangeable $\mathrm{K}$, and had a pH (in $0.01 \mathrm{M} \mathrm{CaCl}_{2}$ ) of 7.81. The soil was passed through a 2-mm sieve and sterilized by radiation with ${ }^{60} \mathrm{Co}$-rays at $10 \mathrm{kGy}$.

\section{Nutrient additions}

The following mineral nutrients at the indicated rates (per $\mathrm{kg}$ soil) were added uniformly before potting: $200 \mathrm{mg} \mathrm{N}\left(\right.$ as KNO$_{3}$ ), $50 \mathrm{mg} \mathrm{Mg}\left(\text { as } \mathrm{MgSO}_{4} \text { ), } 5 \mathrm{mg} \mathrm{Zn} \mathrm{(as} \mathrm{ZnSO}{ }_{4} \cdot 7 \mathrm{H}_{2} \mathrm{O} \text { ), and } 2 \mathrm{mg} \mathrm{Cu} \text { (as CuSO}\right)_{4}$ ). The nutrients were fully mixed with the soil before pot filling. Three weeks after sowing, another $100 \mathrm{mg} \mathrm{N}$ (as $\mathrm{KNO}_{3}$ ) was added to every pot. Three different levels of $\mathrm{P}$ fertilizer (as $\mathrm{K}_{2} \mathrm{HPO}_{4}$ ) were applied: 0,50 and $300 \mathrm{mg} \mathrm{P} \mathrm{kg}^{-1}$ soil; this is equivalent to (as $15 \mathrm{~cm}$ soil depth) 0,75 and $450 \mathrm{~kg} \mathrm{P} \mathrm{ha}^{-1}$. To achieve the same soil $\mathrm{K}$ level between three $\mathrm{P}$ treatments, 377,315 and $0 \mathrm{mg}$ extra $\mathrm{K}$ as $\mathrm{K}_{2} \mathrm{SO}_{4}$ before growing plants was supplied for $P_{0}, P_{50}$ and $P_{300}$, respectively. The Olsen-P contents in rhizosphere soil were 4.5, 9 and $76 \mathrm{mg} \mathrm{kg}^{-1}$, respectively, for the three $P$ levels after harvest.

\section{Inoculum}

The AM fungus Funneliformis mosseae (T.H. Nicolson \& Gerd.) C. Walker \& Schlüßler (formerly Glomusmosseae) isolate was kindly supplied by Prof. Youshan Wang from the Bank of Glomeromycota of China, Institute of Plant Nutrition and Resources, Beijing Academy of Agriculture and Forestry Research, Beijing. The fungus was propagated in a 5:1 mixture $(\mathrm{w} / \mathrm{w})$ of zeolite and river sand with maize for 4 months in a greenhouse, and the inoculum consisted of substrate containing spores, mycelium, and fine-root segments. An 80-g quantity of the inoculum was added to each mycorrhizal pot, and $80 \mathrm{~g}$ of sterilized inoculum was added to non-mycorrhizal pots. To minimize differences in the microbial communities of mycorrhizal and non-mycorrhizal treatments, $10 \mathrm{ml}$ of AMF-free filtrate from the inoculum was added to each non-mycorrhizal pot, and $10 \mathrm{ml}$ of deionized water was added to each mycorrhizal pot.

\section{Cotton varieties}

Eight cotton varieties were used in this experiment, viz., Suk202 (SK202), Xinluzao1 (XLZ1), Junmian1 (JM1), Xinluzao2 (XLZ2), Xinluzao13 (XLZ13), Xinluzhong21 (ZM21), Xinluzhong54 (ZM54), Xinluzao57 (XLZ57). These varieties were released in 1950, 1968, 1979, 1988, 2002, 2004, 2012, and 2013, respectively.

\section{Harvest and analyses}


At harvest after seven weeks plants were separated into shoots and roots. Plant roots were carefully removed from the soil and shaken gently to remove loosely adhering soil. Soil in each pot was collected in a blender to obtain a uniform matrix for subsequent analyses. The shoots were oven-dried at $72{ }^{\circ} \mathrm{C}$ for $72 \mathrm{~h}$ and thereafter ground to a fine powder. Shoot $\mathrm{P}$ concentration was determined by the standard vanado-molybdate method (Murphy and Riley 1962), after the ground shoots were digested in a $\mathrm{H}_{2} \mathrm{SO}_{4}$ $\mathrm{H}_{2} \mathrm{O}_{2}$ mixture at $360^{\circ} \mathrm{C}$ for $2 \mathrm{~h}$.

Roots were washed with deionized water, weighed, and preserved at $-20^{\circ} \mathrm{C}$. Root length and diameter were measured using a WinRHIZO scanning and image-recording system (EPSON 1680, WinRHIZOPro2004b). Specific root length $\left(\mathrm{m} \mathrm{g}^{-1}\right)$ was assessed as the ratio of root length over root dry weight. The proportion of fine-root (roots with a diameter $\leq 0.3 \mathrm{~mm}$ ) length over total root length was determined by WinRHIZO software automatically. We calculated root tissue density, assuming roots as perfect cylinders (Ostonen et al. 2007). After scanning, a weighed subsample of the root system was cleared and stained for assessment of mycorrhizal colonization by the method of Trouvelot et al. (1986). Roots were cut into $1-\mathrm{cm}$ segments, thoroughly mixed, and a $0.5 \mathrm{~g}$ subsample was cleared with $10 \%$ $(\mathrm{w} / \mathrm{v}) \mathrm{KOH}$ at $90^{\circ} \mathrm{C}$ for $2 \mathrm{~h}$ and stained with trypan blue. The rest of roots were oven-dried at $70{ }^{\circ} \mathrm{C}$ for 3 days and weighed. Total root dry weight was determined taking the subsample for mycorrhizal assessment into account. Root/shoot ratio was calculated based on dry weight. Soil samples from each pot were taken for determination of HLD (meters of hyphae gram ${ }^{-1}$ dry soil). HLD was determined according to Jakobsen et al. (1992).

Alkaline phosphatase activity of the rhizosphere [p-nitrophenylphosphate ( $\mathrm{p}-\mathrm{NPP}) ; \mu \mathrm{mol} \mathrm{p}-\mathrm{NPP} \mathrm{h}^{-1} \mathrm{~g}^{-1} \mathrm{dry}$ soil was measured according to Alvey et al. (2001). The roots with tightly adhering rhizosphere soil were transferred into 200-mL vials containing a measured amount of $0.2 \mathrm{mmol} \mathrm{L}^{-1} \mathrm{CaCl}_{2}$ solution depending on root volume (Veneklaas et al. 2003). Roots were repeatedly dipped (about $60 \mathrm{~s}$ ) into the solution until as much rhizosphere soil as possible was removed. Care was taken to minimize root damage. Two 0.5$\mathrm{mL}$ aliquots of soil suspension were transferred into 2-mL centrifuge tubes for measurement of alkaline phosphatase activity (Alvey et al. 2001; Neumann 2006). The pH value of Na-Ac buffer (200 mM) was adjusted to the average $\mathrm{pH}$ value (8.4) of the rhizosphere soil. The rhizosphere soil in the $\mathrm{CaCl}_{2}$ suspension was separated by centrifugation for $10 \mathrm{~min}$ at $12,000 \times \mathrm{g}$, dried at $60^{\circ} \mathrm{C}$, and then weighed. The concentration of para-nitrophenol (p-NP) in the supernatant was measured spectrophotometrically at $405 \mathrm{~nm}$. Acid phosphatase activity at the root surface ( $\mu \mathrm{mol} \mathrm{p-NPP} \mathrm{h}{ }^{-1} \mathrm{~g}^{-1}$ root fresh weight) was measured according to the method of Neumann (2006). Excised cotton root segments were washed 3-5 times in acetate buffer $(0.2 \mathrm{M}, \mathrm{pH} 5.2)$ and immersed in the solution containing $0.5 \mathrm{~mL}$ water, $0.4 \mathrm{~mL}$ acetate buffer $(0.2 \mathrm{M}, \mathrm{pH} 5.2)$ and $0.1 \mathrm{~mL} 0.15 \mathrm{M} \mathrm{p}$-NPP substrate. After reaction for $10 \mathrm{~min}$ at $25 \circ \mathrm{C}, 0.8$ $\mathrm{mL}$ of the reaction mixture was transferred to a new tube, and $0.4 \mathrm{~mL}$ of $0.5 \mathrm{M} \mathrm{NaOH}$ was added to terminate the reaction. The concentration of p-NP was measured spectrophotometrically at $405 \mathrm{~nm}$.

\section{Calculations and statistical analysis}


Absolute mycorrhizal growth/P responsiveness (AMGR/AMPR) refers to mycorrhiza-induced increases in shoot growth and shoot P content. AMR was calculated according to Equation 1 (Janos 2007):

$\mathrm{AMR}=\mathrm{M}-\mathrm{NM}($ Eq. 1)

where $\mathrm{M}$ and NM refer to the shoot biomass or shoot $\mathrm{P}$ content of mycorrhizal and non-mycorrhizal plants, respectively;

Relative mycorrhizal responsiveness/P responsiveness (MGR/MRP) refers to mycorrhiza-induced fractional increases in shoot biomass and shoot $P$ content. MR was calculated according to Equation 2 (Janos 2007):

$M G(P) R=((M-N M) / M) * 100($ Eq. 2)

where $\mathrm{M}$ and NM refer to the shoot biomass or shoot $\mathrm{P}$ content of mycorrhizal and non-mycorrhizal plants, respectively.

Three-way ANOVA was done on shoot dry biomass, shoot $\mathrm{P}$ concentration, shoot $\mathrm{P}$ content, root biomass, root/shoot ratio, root length, specific root length, ratio of fine-root length, root diameter, root tissue density, and phosphatase activity in the rhizosphere and on root surface. Two-way ANOVA was done on mycorrhizal colonization, hyphal length density, and absolute and relative mycorrhizal growth/P response. Because of the large number of comparisons that were partly non independent, we applied Benjamini-Hochberg corrections. One-way ANOVA with Tukey's Honestly Significant Differences test at the $5 \%$ level was done on shoot biomass, shoot $P$ concentration and $P$ content across varieties under six conditions ( 2 mycorrhizal treatment $\times 3 \mathrm{P}$ levels). Correlations between biomass, shoot $\mathrm{P}$ content and 11 root traits at three $\mathrm{P}$ levels and between mycorrhizal colonization and mycorrhizal responsiveness, were calculated using Pearson coefficient.

In order to assess the effect of breeding on varietal performance, we calculated the correlations between year of release, root traits, and plant performance. We also subdivided the eight varieties in two classes (older varieties, released before 1990; younger varieties, released after 2000) and tested through one-way analysis of variance for significant differences between both groups. All analyses were performed with SPSS 20.0 (IBM Corp., Armonk, NY., USA).

\section{Results}

\section{Cotton breeding and root traits}

Averaged over all mycorrhizal and P-level treatments, there was a significantly negative correlation between year of release and root diameter $(r=-0.73, P=0.04)$ and a significantly positive relation between year of release and fine-root fraction and specific root length $(r=0.74, P=0.03 ; r=0.85, P=$ 0.007 respectively), demonstrating that plant breeding had directionally changed root traits towards a doit-yourself strategy at the expense of the (mycorrhizal) collaboration strategy. Other traits did not 
significantly correlate with year of release, indicating that breeding efforts had not resulted in younger cultivars that performed better regardless of soil P supply or mycorrhizal status.

\section{Plant performance}

Table 1 and Figure S1 presents the results of the three-way ANOVA for plant performance. For shoot biomass, shoot $\mathrm{P}$ concentration and shoot $\mathrm{P}$ content all main factors were significant sources of variation. The two-way interactions mycorrhiza $\times \mathrm{P}$ and variety $\times$ mycorrhiza were also significant. The two-way interaction variety $\times \mathrm{P}$ was not significant for these three parameters of plant performance. The highly significant mycorrhiza $\times \mathrm{P}$ interaction in plant biomass was due to the fact that plants responded strongly to mycorrhiza addition at $\mathrm{P}_{0}$ and $\mathrm{P}_{50}$, but did not respond at $\mathrm{P}_{300}$. The same trend was observed for plant $\mathrm{P}$ content and $\mathrm{P}$ concentration, where the mycorrhiza effect also declined at $\mathrm{P}_{300}$.

Averaged over all varieties AMF increased plant biomass with $111 \%$ and $193 \%$ at $P_{0}$ and $P_{50}$, and reduced biomass with $1 \%$ at $P_{300}$ (Fig. 1a). For shoot $P$ concentration, the mycorrhizal effect was largest at $P_{50}$ (188\%), followed by $P_{0}$ and $P_{300}$ (79\% and $41 \%$ respectively; Fig. 1 b). Total shoot $P$ content also showed the largest mycorrhizal effect at $\mathrm{P}_{50}\left(744 \%\right.$ increase), followed by $\mathrm{P}_{0}\left(278 \%\right.$ increase) and $\mathrm{P}_{300}(39 \%$ increase) (Fig. 1c). Mycorrhizal plants at $\mathrm{P}_{0}$ had the same biomass and a significantly higher $\mathrm{P}$ content than non-mycorrhizal plants at $P_{50}$. Mycorrhizal plants at $P_{50}$ had a lower biomass than non-mycorrhizal plants at $P_{300}$, whereas $P$ content of both groups of plants was not significantly different. These comparisons suggest substantial potential to save $P$ fertilizer with adequate mycorrhizal management and varietal selection.

Root biomass and root length showed the same main effects as those of aboveground performance (Table 1). Root biomass and root length increased with increasing P levels (Fig. S2). In the presence of mycorrhiza, root biomass and root length were also higher than in the non-mycorrhizal condition at $P_{0}$ and especially at $P_{50}$, similar to the strong mycorrhiza $\times P$ interaction for above-ground traits. At $P_{300}$, mycorrhiza had no significant effect on root biomass and root length (Table 1 and Fig. S2).

Older varieties were, at $\mathrm{P}_{0}$ and $\mathrm{P}_{50}$, more productive than younger varieties both in the non-mycorrhizal and in the mycorrhizal condition (Fig. S3). This difference disappeared at $\mathrm{P}_{300}$. Root biomass tended to be higher in the old varieties than in the more modern varieties, especially in the mycorrhizal condition (Fig. S4a), whereas root length of older varieties at $P_{50}$ was smaller than that of modern varieties (Fig. $S 4 b)$.

\section{Mycorrhizal response}

Absolute and relative mycorrhizal responsiveness and mycorrhizal $\mathrm{P}$ responses were also significantly affected by variety, $\mathrm{P}$ level and the interaction variety $\times \mathrm{P}$ level. (Table 1 ). All four parameters were highest at $P_{50}$, an effect that was stronger for absolute responsiveness than for relative responsiveness (Fig. 2). At $\mathrm{P}_{300}$, absolute and relative mycorrhizal responsiveness were not different from zero, but absolute and 
relative mycorrhizal $P$ responsiveness were still positive, indicating that cotton plants benefitted from AMF even at the highest $P$ level. At $P_{0}$ and $P_{50}$, relative mycorrhizal responsiveness, mycorrhizal $P$ responsiveness and absolute mycorrhizal growth response were significantly negatively correlated with shoot biomass and $\mathrm{P}$ content of non-mycorrhizal plants (Table S1). Older varieties tended to have a lower MGR (at $P_{0}: 46 \%$ vs $56 \%$; at $P_{50}: 62 \%$ vs $67 \%$; at $P_{300}: 1.4 \%$ vs $-6.0 \%$ ), but a higher AMGR (at $P_{0}: 1.0$ vs

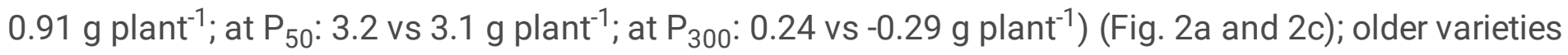
also tended to have a lower MPR (at $P_{0}: 70 \%$ vs $73 \%$; at $P_{50}: 87 \%$ vs $88 \%$; at $P_{300}: 31 \%$ vs $23 \%$ ), but a higher AMPR (at $\mathrm{P}_{0}: 2.7$ vs 2.0 mg plant $^{-1}$; at $\mathrm{P}_{50}: 14$ vs 12 mg plant $^{-1}$; at $\mathrm{P}_{300}: 6.3$ vs $4.5 \mathrm{mg} \mathrm{plant}^{-1}$ ) $\left(\right.$ Fig. $^{\circ}$. $2 b$ and $2 d)$.

\section{Root trait variation}

For the morphological trait root diameter, only variety was a significant source of variation, for root tissue density (RTD) only mycorrhiza was a significant source of variation (Table 1). Specific root length was significantly affected by variety and mycorrhiza. Non-mycorrhizal plants had a significantly higher RTD than mycorrhizal plants, 0.059 vs $0.056 \mathrm{~g} \mathrm{~cm}^{-3}$ respectively. The proportion of fine-root length, which is determined by both average root diameter and the degree of root branching, was significantly affected by variety, mycorrhiza, P level, and the interactions variety $\times$ mycorrhiza and mycorrhiza $\times \mathrm{P}$ level (Table 1 and Fig. S5). The proportion of fine-root length decreased with increasing P application (Fig. S5). Modern varieties had higher SRL and a larger proportion of fine-root length than older varieties (Fig. S6).

Both physiological root traits, phosphatase activity in the rhizosphere and on the root surface, were significantly affected by variety, mycorrhiza and P level (Table 1). Both decreased with increasing P levels (Fig. S7). Some varieties increased phosphatase levels when mycorrhizal, while other varieties showed an opposite pattern (Fig. S7).

Non-inoculated treatments remained free from colonization by AMF. Mycorrhizal colonization and hyphal length density were significantly affected by variety, $\mathrm{P}$ level and the interaction variety $\times \mathrm{P}$ level (Table 1 ). Mycorrhizal colonization was lower at the extreme $P$ levels $\left(P_{0}\right.$ and $\left.P_{300}\right)$ than at $P_{50}$ (Fig. 3a). Hyphal length density decreased with increasing $\mathrm{P}$ (Fig. $3 b$ ). For all mycorrhizal root traits there were significant varietal differences, however these differences varied with $\mathrm{P}$ levels and no clear pattern was observed.

\section{Correlations between plant performance (shoot biomass, shoot $\mathrm{P}$ content) and root traits}

Correlations between plant performance parameters (biomass and P content of shoots) and root traits are provided in Tables 2 and 3. At $\mathrm{P}_{0}$, performance of non-mycorrhizal plants was predicted by phosphatase activity on the root surface. There were no significant relationships between mycorrhizalplant performance and root traits at $\mathrm{P}_{0}$. At $\mathrm{P}_{50}$, performance of non-mycorrhizal plants was not significantly correlated with any root trait. For mycorrhizal plants there was a significantly positive correlation between root diameter and plant biomass and P content. Mycorrhizal colonization and hyphal length density were also positively correlated, but the correlation was not significant (Table 2). At $\mathrm{P}_{300}$, 
there were no significant correlations between root traits and plant performance. Physiological root traits, phosphatase activity on the root surface and in the rhizosphere, were not correlated with shoot $\mathrm{P}$ uptake at $P_{50}$ and $P_{300}$, suggesting that these physiological traits are not good indicators when screening cotton varieties for high $\mathrm{P}$ uptake efficiency under conditions of ample to high supply of mineral fertilizer.

At $\mathrm{P}_{50}$, mycorrhizal colonization was positively correlated with MGR, MPR, AMGR and AMPR (Fig. 4), indicating that mycorrhizal colonization is important for plant biomass and plant $P$ uptake. However, at $P_{0}$ and $P_{300}$, the correlations were not significant (data not shown). In addition, there were significantly negative correlations between shoot biomass of non-mycorrhizal plants and AMGR at each soil $P$ level $(r$ $=-0.52, P<0.01 ; r=-0.38, P<0.05 ; r=-0.63, P<0.001 ;$ at $P_{0}, P_{50}$, and $P_{300}$ respectively; Table $\left.S 1\right)$, confirming that larger plants had lower mycorrhizal responsiveness.

\section{Discussion}

Our study showed that cotton breeding had directionally changed root traits, as varieties that were more recently released had on average thinner roots than older varieties. A consequence of this varietal selection is that modern cotton varieties more exhibited a do-it-yourself $P$ acquisition strategy and became less reliant on a collaborative strategy with AMF. As cotton is strongly responsive to the AMF symbiosis, such likely inadvertent and indirect selection against mycorrhizal symbiosis strongly suggests the need for redirecting breeding efforts, considering the need to reduce the currently unsustainable $P$ levels that are commonly used in cotton cultivation.

\section{Mycorrhizal benefits of cotton plants}

Our data showed that cotton is highly responsive to mycorrhiza. Compared with non-inoculated controls, mycorrhizal cotton plants increased biomass with 111-193\% (at $\mathrm{P}_{0}$ and $\mathrm{P}_{50}$ ) and plant $\mathrm{P}$ content with 39$744 \%$, depending on $\mathrm{P}$ levels. Large beneficial effects of AMF on biomass, shoot $\mathrm{P}$ concentration and plant $\mathrm{P}$ content were also reported by Nehl and McGee (2010). Root traits of cotton roots confirm its strong interaction with AMF. Cotton has roots with an average diameter $(0.45 \mathrm{~mm}$, similar to the average root diameter of $0.44 \mathrm{~mm}$ in Guerrero-Ramirez et al. (2021), but the cortical cells are fairly large, resulting in a very low root tissue density $\left(0.05 \mathrm{~g} \mathrm{~cm}^{-3}\right.$, the average in Guerrero-Ramirez et al. (2021) being $0.25 \mathrm{~g}$ $\mathrm{cm}^{-3}$ ) and providing large physical space for AMF. Martin-Robles et al. (2019) also indicated very low RTD for cotton $\left(0.086 \mathrm{~g} \mathrm{~cm}^{-3}\right)$, slightly higher than reported for our cotton varieties. Reported levels of colonization of cotton roots show large variation, related to soil properties, cotton variety, AMF species, and possibly management. Mycorrhizal colonization was highest at the intermediate $P$ level, consistent with the unimodal relation between soil $\mathrm{P}$ availability and root colonization reported by Eskandari et al. (2017). Large variation in mycorrhizal colonization of roots of different cotton roots was reported by Damodaran et al. (2012), who noted for ten cultivars colonization varying between 37 and $74 \%$. Variation in colonization can additionally be linked to selectivity of cotton roots for certain species of AMF. Salgado et al. (2017) compared five species of AMF and noted root colonization levels of around $20 \%$ for four species but around $90 \%$ by Rhizophagus clarus, however levels of colonization were not correlated with 
plant biomass. Another factor that determines variability in colonization in different studies could be inoculum limitation to achieve maximum colonization. Zak et al. (1998) reported much higher colonization levels when cotton was grown in fields in which wheat was previously grown than in fields with cotton under conventional tillage. Cely et al. (2016) noted colonization levels of $80 \%$ when cotton was inoculated with $R$. clarus, but only $50 \%$ in the field without inoculum addition. Inoculum limitation could possibly an issue in plant breeding arenas, a topic that has not received much attention.

In this study, at $\mathrm{P}_{50}$, shoot $\mathrm{P}$ concentration with AMF was significantly higher than that without $A M F$ at $P_{300}$ (Fig. 1b), and shoot $P$ content with $A M F$ at $P_{50}$ was not significantly different from that without AMF at $P_{300}$ (Fig. 1C), suggesting substantial $P$ fertilizer savings potential for growing cotton plants when considering AMF. Several studies have equally shown possibilities for substantial fertilizer savings with adequate mycorrhizal management. Wang et al. (2020b) showed that performance of normal mycorrhizal maize plants at low $\mathrm{P}$ availability was almost equal to that of reduced-mycorrhizal plants at much higher $\mathrm{P}$ availability. Mai et al. (2018) found that a 50\% $\mathrm{P}$ application rate increased both root length and hyphal length compared to a $100 \%$ application rate, and while saving $50 \%$, these plants obtained $80-90 \%$ of the yield of the high application rate. Considering that older varieties relied more on and benefitted more from collaboration with AMF, a mycorrhizal focus both at management level and at varietal choice for cotton seems imperative.

\section{Breeding cotton for mycorrhizal symbiosis}

Differential performance of varieties with respect to mycorrhizal benefit, either absolute or relative, as shown in our study, has been more frequently reported by Kuyper et al. (2021). In a number of cases older varieties exhibited a larger relative mycorrhizal responsiveness and such observations have given rise to the hypothesis that plant breeding under the current, often nutrient-rich, conditions has inadvertently selected against mycorrhizal responsiveness; and that therefore mycorrhizal responsiveness has to be reintroduced in plant breeding for sustainable agriculture. It has become clear, however, that the use of relative mycorrhizal responsiveness as a potential selection target for breeding is highly problematical (Galván et al. 2011; Kaeppler et al. 2000; Sawers et al. 2010). Because the performance of the nonmycorrhizal plant is in the formula of relative responsiveness (formula 2), the (negative) relationship is partly mathematical rather than biological, with the highest values for relative responsiveness being associated with the plants that perform most poorly when non-mycorrhizal. These properties make relative responsiveness an unlikely desirable trait from the perspective of plant breeding. We also noted a negative correlation, at $\mathrm{P}_{0}$ and $\mathrm{P}_{50}$, between performance of the non-mycorrhizal cotton plant and relative mycorrhizal responsiveness (at $P_{0}: r=-0.81$; at $P_{50}: r=-0.77$; Table $S 1$ ), confirming its unsuitability as a selection target.

An alternative approach, suggested by Janos (2007) and Galván et al. (2011), could be to use absolute mycorrhizal responsiveness, as in our formula 1. Applying that formula also showed a significant, negative relationship between performance of the non-mycorrhizal plant and absolute mycorrhizal responsiveness (at $P_{0}$ and $P_{50}: r=-0.52$ and -0.38 respectively; Table $S 1$ ). That method thereby provides 
no clear criterion for selection for enhanced benefit from the mycorrhizal symbiosis, as plant breeders will ultimately be interested in the largest plants with the highest P content under normal field conditions, i.e., when plants are mycorrhizal.

Finally, Sawers et al. (2010) proposed a method to separate between what they referred to as dependence-based and non-dependence based variation in responsiveness, by regressing performance of non-mycorrhizal against mycorrhizal plants and partitioning the variance, with the dependence-based part of responsiveness being equal to the $r^{2}$ of the regression, and the non-dependence part (and the possible target for selection) being the residual variation. That method is likely problematical, as the nondependence part includes random variation or statistical noise. Application of the method at $P_{50}$, as the more likely soil fertility condition for the selection arena, indicated that both parameters were uncorrelated $(r=-0.08$; data not shown), and that therefore selection based on this method would equate selection for the best performing plants in the mycorrhizal condition, independent of the (absolute or relative) benefit that the plant received from being mycorrhizal.

There was no significant relation between mycorrhizal colonization and the year of variety release (Fig. 3a), which is consistent with An et al. (2010) who found that modern plant breeding programs in maize did not lead to the suppression of colonization by comparing 141 inbred lines, 38 hybrids, and 76 landraces. In general, mycorrhizal colonization is an important predictor mycorrhizal responsiveness (Lehmann et al. 2012; Lekberg and Koide 2005). In our study, mycorrhizal colonization at $\mathrm{P}_{50}$ was significantly positively correlated with absolute and relative mycorrhizal responsiveness and mycorrhizal $P$ responsiveness (Fig. 4), suggesting that varietal selection for high mycorrhizal colonization could be a strategy to improve cotton growth and $\mathrm{P}$ efficiency. Mycorrhizal colonization is correlated with root diameter and especially cortical area (Valverde-Barrantes et al. 2016), and so the positive relation between mycorrhizal colonization and plant performance could be mediated by root diameter, which would suggest that root diameter as a reflection of the underlying strategy in the root economics space might be the direct target for selection.

Plant biomass was larger for the four varieties that were released before 2000 than that of the four varieties released after 2000. Those older varieties also had thicker roots (and root diameter was the best predictor for plant performance at $\mathrm{P}_{50}$; Tables 2 and 3), lower SRL, and lower fine-root fraction than more modern varieties. We therefore concluded that breeding had resulted in cotton plants with thinner roots and reduced collaboration with AMF (Bergmann et al. (2020) that, consequently, performed more poorly except under conditions of very high and unsustainable $\mathrm{P}$ supply. Only at that very high $\mathrm{P}$ supply $\left(\mathrm{P}_{300}\right)$ did differences between the varieties disappear.

It is currently not clear why cotton breeding has resulted in plants with thinner roots. Cotton plants with thicker roots (and with more mycorrhizal collaboration) not only acquired more $\mathrm{P}$, but other studies have shown that cotton plants with thicker roots are more tolerant of drought (McMichael et al. 1985) and have higher levels of mycorrhizal colonization, contributing to alleviation of salinity stress (Liu et al. 2016). One possible explanation for breeding for thinner roots could be that in hydroponic systems cotton 
plants with thinner roots and higher SRL were more P-efficient (Chen et al. 2019). Martin-Robles et al. (2019) compared thirty domesticated pants with their wild progenitors. While they noted no consistent pattern of domestication on root diameter, the data for cotton indicated that cotton breeding has resulted in a significant shift towards thinner roots than its wild progenitor. A possible explanation for this selection effect could have been domestication towards a more annual life style, with possible consequences of selection for a larger reproductive output and a shift towards a larger investment in aboveground tissues and a lower investment in roots. A similar shift towards a more annual life style, in combination with a larger reproductive output, a lower root/shoot ratio, thinner roots and a lower mycorrhizal responsiveness, has been noted for the invasive plant Hypericum perforatum L. in North America compared to its native conspecific plants in Europe. This selection towards an annual life style could have been especially successful in a more nutrient-rich and/or AMF-depleted environment (Seifert et al. 2009). The breeding arena for cotton likely reflects such an environmental shift. A further explanation is suggested through the work by Xiao et al. (2020). They noted a positive correlation between root diameter and root life span and also observed that drought induced enhanced root turnover. They therefore suggested that under drought plants with thinner roots are in an advantageous position.

\section{Conclusions}

All eight cotton varieties were responsive to AMF. Cotton plants exhibited the collaborative strategy in the root economics space as defined by Bergmann et al. (2020). However, over time cotton breeding has resulted in thinner roots, implying a shift towards a do-it-yourself strategy, but that switch resulted in a reduced performance of these more recent varieties, except at the highest $P$ level. In order to achieve good cotton yields while reducing fertilizer $\mathrm{P}$ application, to achieve more environmental sustainability and to reduce the negative environmental impacts of overuse of fertilizer, breeding efforts should be directed at the interplay of root traits and mycorrhiza-related traits, in order to move away from what can best be described as inadvertent plant breeding against mycorrhizal symbiosis.

\section{Declarations}

\section{Acknowledgements}

This study was financially supported by the National Natural Science Foundation of China (U1703232). XXW is supported by State Key Laboratory of North China Crop Improvement and Regulation.

\section{Author Contributions}

J.D.S and G.F. designed the experiment. M.Z performed the experiments, collected the samples and the data. X.X.W and T.W.K. analyzed the data and drafted the manuscript. All authors discussed the results and commented on the manuscript. J.D.S and G.F. acquired funding for the study. All authors agree with the submission of this version.

\section{All authors claim no conflict of interest.}




\section{References}

Alvey S, Bagayoko M, Neumann G, Buerkert A (2001) Cereal/legume rotations affect chemical properties and biological activities in two West African soils. Plant Soil 231: 45-54.

An GH, Kobayashi S, Enoki H, Sonobe K, Muraki M, Karasawa T, Ezawa T (2010) How does arbuscular mycorrhizal colonization vary with host plant genotype? An example based on maize (Zea mays) germplasms. Plant Soil 327: 441-453.

Bardgett RD, Mommer L, De Vries FT (2014) Going underground: root traits as drivers of ecosystem processes. Trends Ecol Evol 29: 692-699.

Bergmann J, Weigelt A, van Der Plas F, Laughlin DC, Kuyper TW, Guerrero-Ramirez NR, Valverde-Barrantes OJ, Bruelheide H, Freschet GT, Iversen CM, Kattge J, Mccormack ML, Meier IC, Rillig MC, Roumet C, Semchenko M, Sweeney CJ, van Ruijven J, York LM, Mommer L (2020) The fungal collaboration gradient dominates the root economics space in plants. Sci Adv 6: article eaba3756.

Blaas H, Kroeze C (2016) Excessive nitrogen and phosphorus in European rivers: 2000-2050. Ecol Indic 67: 328-337.

Cely MVT, de Oliveira AG, de Freitas VF, de Luca MB, Barazetti AR, dos Santos IMO, Gionco B, Garcia GV, Prete CEC, Andrade G (2016) Inoculant of arbuscular mycorrhizal fungi (Rhizophagus clarus) increase yield of soybean and cotton under field conditions. Front Microbiol 7: article 720.

Chen BL, Wang QH, Bucking H, Sheng JD, Luo J, Chai ZP, Kafle A, Hou YY, Feng G (2019) Genotypic differences in phosphorus acquisition efficiency and root performance of cotton (Gossypium hirsutum) under low-phosphorus stress. Crop Pasture Sci 70: 344-358.

Chu Q, Wang XX, Yang Y, Chen FJ, Zhang FS, Feng G (2013) Mycorrhizal responsiveness of maize (Zea mays L.) genotypes as related to releasing date and available P content in soil. Mycorrhiza 23: 497-505.

Damodaran PN, Udaiyan K, Roh KS (2012) Mycorrhizal dependency in certain Indian cotton cultivars. Res Plant Biol 2: 55-66.

Eskandari S, Guppy CN, Knox OGG, Backhouse D, Haling RE (2018) Understanding the impact of soil sodicity on mycorrhizal symbiosis: Some facts and gaps identified from cotton systems. Applied Soil Ecology 126: 199-201.

Eskandari S, Guppy CN, Knox OGG, Flavel RJ, Backhouse D, Haling RE (2017) Mycorrhizal contribution to phosphorus nutrition of cotton in low and highly sodic soils using dual isotope labelling $\left({ }^{32} \mathrm{P}\right.$ and $\left.{ }^{33} \mathrm{P}\right)$. Soil Biol Biochem 105: 37-44.

Fageria NK (2014) Growth, nutrient uptake, and use efficiency in dry bean in tropical upland soil. J Plant Nutr 37: 2085-2093. 
Fageria NK, Gheyi HR, Carvalho MCS, Moreira A (2016) Root growth, nutrient uptake and use efficiency by roots of tropical legume cover crops as influenced by phosphorus fertilization. J Plant Nutr 39: 781-792.

Galván GA, Kuyper TW, Burger K, Keizer LCP, Hoekstra RF, Kik C, Scholten OE (2011) Genetic analysis of the interaction between Allium species and arbuscular mycorrhizal fungi. Theor Appl Genet 122: 947-960.

Gao XP, Kuyper TW, Zou CQ, Zhang FS, Hoffland E (2007) Mycorrhizal responsiveness of aerobic rice genotypes is negatively correlated with their zinc uptake when nonmycorrhizal. Plant Soil 290: 283-291.

Gill MA, Sabir M, Ashraf S, Rahmatullah., Aziz T (2005) Effect of P-stress on growth, phosphorus uptake and utilization efficiency of different cotton cultivars. Pak J Agr Sci 42: 42-47.

Guerrero-Ramirez NR, Mommer L, Freschet GT, Iversen CM, McCormack ML, Kattge J, Poorter H, van der Plas F, Bergmann J, Kuyper TW, York LM, Bruelheide H, Laughlin DC, Meier IC, Roumet C, Semchenko M, Sweeney CJ, van Ruijven J, Valverde-Barrantes OJ, Aubin I, Catford JA, Manning P, Martin A, Milla R, Minden V, Pausas JG, Smith SW, Soudzilovskaia NA, Ammer C, Butterfield B, Craine J, Cornelissen JHC, de Vries FT, Isaac ME, Kramer K, Konig C, Lamb EG, Onipchenko VG, Penuelas J, Reich PB, Rillig MC, Sack L, Shipley B, Tedersoo L, Valladares F, van Bodegom P, Weigelt P, Wright JP, Weigelt A (2021) Global root traits (GRooT) database. Global Ecol Biogeogr 30: 25-37.

Hodge A, Berta G, Doussan C, Merchan F, Crespi M (2009) Plant root growth, architecture and function. Plant Soil 321: 153-187.

Jakobsen I, Abbott LK, Robson AD (1992) External hyphae of vesicular arbuscular mycorrhizal fungi associated with Trifolium subterraneum I. 2. Hyphal transport of ${ }^{32} \mathrm{P}$ over defined distances. New Phytol 120: 509-516.

Janos DP (2007) Plant responsiveness to mycorrhizas differs from dependence upon mycorrhizas. Mycorrhiza 17: 75-91.

Kaeppler SM, Parke JL, Mueller SM, Senior L, Stuber C, Tracy WF (2000) Variation among maize inbred lines and detection of quantitative trait loci for growth at low phosphorus and responsiveness to arbuscular mycorrhizal fungi. Crop Sci 40: 358-364.

Kidd DR, Ryan MH, Haling RE, Lambers H, Sandral GA, Yang Z, Culvenor RA, Cawthray GR, Stefanski A, Simpson RJ (2015) Rhizosphere carboxylates and morphological root traits in pasture legumes and grasses. Plant Soil: 1-13.

Kuyper TW, Wang XX, Muchane MN (2021) The interplay between roots and arbuscular mycorrhizal fungi influencing water and nutrient acquisition and use efficiency. In: Rengel Z, Djalovic I (eds) The Root Systems in Sustainable Agricultural Intensification. John Wiley \& Sons Inc, New Jersey, USA. 
Lambers H, Shane MW, Cramer MD, Pearse SJ, Veneklaas EJ (2006) Root structure and functioning for efficient acquisition of phosphorus: matching morphological and physiological traits. Ann Bot 98: 693713.

Lehmann A, Barto EK, Powell JR, Rillig MC (2012) Mycorrhizal responsiveness trends in annual crop plants and their wild relatives-a meta analysis on studies from 1981 to 2010. Plant Soil 355: 231-250.

Lekberg Y, Koide RT (2005) Is plant performance limited by abundance of arbuscular mycorrhizal fungi? A meta-analysis of studies published between 1988 and 2003. New Phytol 168: 189-204.

Li H, Ma Q, Li H, Zhang F, Rengel Z, Shen J (2014) Root morphological responses to localized nutrient supply differ among crop species with contrasting root traits. Plant Soil 376: 151-163.

Liu SL, Guo XL, Feng G, Maimaitiaili B, Fan JL, He XH (2016) Indigenous arbuscular mycorrhizal fungi can alleviate salt stress and promote growth of cotton and maize in saline fields. Plant Soil 398: 195-206.

Liu Y, Villalba G, Ayres RU, Schroder H (2008) Global phosphorus flows and environmental impacts from a consumption perspective. J Ind Ecol 12: 229-247.

Lynch JP (2019) Root phenotypes for improved nutrient capture: an underexploited opportunity for global agriculture. New Phytol undefined: undefined.

Lyu Y, Tang HL, Li HG, Zhang FS, Rengel Z, Whalley WR, Shen JB (2016) Major crop species show differential balance between root morphological and physiological responses to variable phosphorus supply. Front Plant Sci 7: article 1939.

Mai W, Xue X, Feng G, Yang R, Tian C (2018) Can optimization of phosphorus input lead to high productivity and high phosphorus use efficiency of cotton through maximization of root/mycorrhizal efficiency in phosphorus acquisition? Field Crop Res 216: 100-108.

Martin-Robles N, Morente-Lopez J, Freschet GT, Poorter H, Roumet C, Milla R (2019) Root traits of herbaceous crops: Pre-adaptation to cultivation or evolution under domestication? Funct Ecol 33: 273285.

McMichael BL, Burke JJ, Berlin JD, Hatfield JL, Quisenberry JE (1985) Root vascular bundle arrangements among cotton strains and cultivars. Environ Exp Bot 25: 23-30.

Murphy J, Riley JP (1962) A modified single solution method for the determination of phosphate in natural waters. Anal Chim Acta 27: 31-36.

NehI DB, McGee PA (2010) Ecophysiology of arbuscular mycorrhizas in cotton. In: Stewart JM, Oosterhuis DM, Heitholt JJ, Mauney JR (eds) Physiology of Cotton. Springer Netherlands, Dordrecht. 206-212. 
Neumann G (2006) Quantitative determination of acid phosphatase activity in the rhizosphere and on the root surface. In: Luster, J, Finlay, R (Eds), Handbook of Methods used in Rhizosphere Research: 418-442.

Ostonen I, Püttsepp Ü, Biel C, Alberton O, Bakker M, Lõhmus K, Majdi H, Metcalfe D, Olsthoorn A, Pronk A (2007) Specific root length as an indicator of environmental change. Plant Biosyst 141: 426-442.

Pang J, Yang J, Lambers H, Tibbett M, Siddique KHM, Ryan MH (2015) Physiological and morphological adaptations of herbaceous perennial legumes allow differential access to sources of varyingly soluble phosphate. Physiol Plantarum 154: 511-525.

Raghothama KG (1999) Phosphate acquisition. Annu Rev Plant Phys 50: 665-693.

Reich PB (2014) The world-wide 'fast-slow' plant economics spectrum: a traits manifesto. J Ecol 102: 275-301.

Ryan MH, Tibbett M, Edmonds-Tibbett T, Suriyagoda LDB, Lambers H, Cawthray GR, Pang J (2012) Carbon trading for phosphorus gain: the balance between rhizosphere carboxylates and arbuscular mycorrhizal symbiosis in plant phosphorus acquisition. Plant Cell Environ 35: 2170-2180.

Salgado FHM, Moreira FMD, Siqueira JO, Barbosa RH, Paulino HB, Carneiro MAC (2017) Arbuscular mycorrhizal fungi and colonization stimulant in cotton and maize. Cienc Rural 47.

Sawers RJH, Gebreselassie MN, Janos DP, Paszkowski U (2010) Characterizing variation in mycorrhiza effect among diverse plant varieties. Theor Appl Genet 120: 1029-1039.

Sawers RJH, Gutjahr C, Paszkowski U (2008) Cereal mycorrhiza: an ancient symbiosis in modern agriculture. Trends Plant Sci 13: 93-97.

Seifert EK, Bever JD, Maron JL (2009) Evidence for the evolution of reduced mycorrhizal dependence during plant invasion. Ecology 90: 1055-1062.

Trouvelot A, Kough, Gianiazzi-Pearson V (1986) Mesure du taux de mycorrhization VA d'un système radiculaire. Recherche de methodsd'estimation ayant une signification fonctionnelle. In: GianinazziPearson V and Gianinazzi S (eds.). Physiological Genetical Aspects of Mycorrhizae. INRA Press, Paris, France. pp. 217-221.

Valverde-Barrantes OJ, Horning AL, Smemo KA, Blackwood CB (2016) Phylogenetically structured traits in root systems influence arbuscular mycorrhizal colonization in woody angiosperms. Plant Soil 404: 1-12.

Vance CP, Uhde-Stone C, Allan DL (2003) Phosphorus acquisition and use: critical adaptations by plants for securing a nonrenewable resource. New Phytol 157: 423-447.

Veneklaas EJ, Stevens J, Cawthray GR, Turner S, Grigg AM, Lambers H (2003) Chickpea and white lupin rhizosphere carboxylates vary with soil properties and enhance phosphorus uptake. Plant Soil 248: 187- 
197.

Wang XJ, Tang CX, Guppy CN, Sale PWG (2010) Cotton, wheat and white lupin differ in phosphorus acquisition from sparingly soluble sources. Environ Exp Bot 69: 267-272.

Wang XX, Li HB, Chu Q, Feng G, Kuyper TW, Rengel Z (2020a) Mycorrhizal impacts on root trait plasticity of six maize varieties along a phosphorus supply gradient. Plant Soil 448: 71-86.

Wang XX, van der Werf W, Yu Y, Hoffland E, Feng G, Kuyper TW (2020b) Field performance of different maize varieties in growth cores at natural and reduced mycorrhizal colonization: Yield gains and possible fertilizer savings in relation to phosphorus application. Plant Soil 450: 613-624.

Wen ZH, Li HB, Shen Q, Tang XM, Xiong CY, Li HG, Pang JY, Ryan MH, Lambers H, Shen JB (2019) Tradeoffs among root morphology, exudation and mycorrhizal symbioses for phosphorus-acquisition strategies of 16 crop species. New Phytol 223: 882-895.

Xiao S, Liu LT, Zhang YJ, Sun HC, Zhang K, Bai ZY, Dong HZ, Li CD (2020) Fine root and root hair morphology of cotton under drought stress revealed with RhizoPot. J Agron Crop Sci 206: 679-693.

Yan Z, Liu P, Li Y, Ma L, Alva A, Dou Z, Chen Q, Zhang F (2013) Phosphorus in China's intensive vegetable production systems: overfertilization, soil enrichment, and environmental implications. J Environ Qual 42: 982-989.

Zak JC, McMichael B, Dhillion S, Friese C (1998) Arbuscular-mycorrhizal colonization dynamics of cotton (Gossypium hirsutum L.) growing under several production systems on the Southern High Plains, Texas. Agr Ecosyst Environ 68: 245-254.

Zhang WF, Ma WQ, Ji YX, Fan MS, Oenema O, Zhang FS (2008) Efficiency, economics, and environmental implications of phosphorus resource use and the fertilizer industry in China. Nutr Cycl Agroecosys 80: 131-144.

Zhu JM, Lynch JP (2004) The contribution of lateral rooting to phosphorus acquisition efficiency in maize (Zea mays) seedlings. Funct Plant Biol 31: 949-958.

\section{Tables}

Table 1 Three- or two-way ANOVA results with cotton varieties, mycorrhiza and P levels as independent variables. 


\begin{tabular}{|c|c|c|c|c|c|c|c|}
\hline Variables & $\begin{array}{l}\text { Varieties } \\
\text { (V) }\end{array}$ & $\begin{array}{l}\text { Mycorrhiza } \\
\text { (M) }\end{array}$ & $\begin{array}{l}\text { P level } \\
(P)\end{array}$ & $V * M$ & $V * P$ & $M * P$ & $\begin{array}{l}V * M \\
* P\end{array}$ \\
\hline Shoot biomass & $3.5^{\star \star}$ & $315^{\star \star \star}$ & $1423^{\star \star \star}$ & $2.5^{\star}$ & $1.9 \mathrm{~ns}$ & $157 * \star \star$ & $1.6 \mathrm{~ns}$ \\
\hline $\begin{array}{l}\text { Shoot P } \\
\text { concentration }\end{array}$ & $5.2^{\star \star \star}$ & $1474 * \star \star$ & $515^{\star \star \star}$ & $5.9 \star \star \star$ & $1.8 \mathrm{~ns}$ & $157 * \star \star$ & $1.3 \mathrm{~ns}$ \\
\hline Shoot $\mathrm{P}$ content & $3.9 * \star$ & $1019 * \star \star$ & $1439 * \star \star$ & $6.4^{\star \star \star}$ & $1.8 \mathrm{~ns}$ & $210 \star \star \star$ & $2.3^{\star \star}$ \\
\hline Root biomass & $11^{\star \star \star}$ & $188^{\star \star \star *}$ & $816^{\star \star \star}$ & 2.9 ** & $1.9 \mathrm{~ns}$ & $126^{\star \star \star}$ & $2.3^{*}$ \\
\hline Root shoot ratio & $2.4^{\star}$ & $8.7^{\star \star}$ & 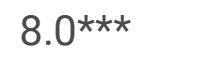 & $2.1 \mathrm{~ns}$ & $1.4 \mathrm{~ns}$ & $10 \star \star \star *$ & $0.52 \mathrm{~ns}$ \\
\hline Root length & $4.0^{\star \star \star *}$ & $132^{\star \star \star *}$ & $504^{\star \star \star}$ & $2.2 \mathrm{~ns}$ & $1.8 \mathrm{~ns}$ & $57 * \star \star$ & $2.5^{\star \star}$ \\
\hline Mean root diameter & $6.0 * * *$ & $0.03 n s$ & $0.75 \mathrm{~ns}$ & $0.44 \mathrm{~ns}$ & $1.1 \mathrm{~ns}$ & $0.81 \mathrm{~ns}$ & $0.96 n s$ \\
\hline Root tissue density & $0.61 \mathrm{~ns}$ & $6.9 * \star \star$ & $2.1 \mathrm{~ns}$ & $0.39 n s$ & $1.1 \mathrm{~ns}$ & 1.0ns & $1.0 \mathrm{~ns}$ \\
\hline $\begin{array}{l}\text { Proportion of fine } \\
\text { root length }\end{array}$ & $10 \star \star \star$ & $0.56 \mathrm{~ns}$ & $6.3^{\star \star}$ & $2.7^{\star \star}$ & $1.6 \mathrm{~ns}$ & $4.4^{\star}$ & $1.2 \mathrm{~ns}$ \\
\hline Specific root length & $5.5^{\star \star \star}$ & $6.7^{\star \star \star}$ & $2.9 \mathrm{~ns}$ & $1.2 \mathrm{~ns}$ & $1.9 \mathrm{~ns}$ & $1.4 \mathrm{~ns}$ & $1.6 \mathrm{~ns}$ \\
\hline $\begin{array}{l}\text { Phosphatase activity } \\
\text { on root surface at pH } \\
5.2\end{array}$ & $3.2^{\star \star}$ & $7.3^{\star \star}$ & $30 * \star *$ & $2.1 \mathrm{~ns}$ & $0.36 n s$ & $0.10 \mathrm{~ns}$ & $0.15 \mathrm{~ns}$ \\
\hline $\begin{array}{l}\text { Phosphatase activity } \\
\text { of rhizosphere soil at } \\
\mathrm{pH} 8.2\end{array}$ & $2.2^{\star}$ & $7.1^{\star \star}$ & $22^{\star \star \star}$ & $2.4 \mathrm{~ns}$ & $0.93 \mathrm{~ns}$ & $4.3^{*}$ & $1.2 \mathrm{~ns}$ \\
\hline $\begin{array}{l}\text { Mycorrhizal } \\
\text { colonization }\end{array}$ & $86^{\star \star \star}$ & & $14509 * \star \star$ & & $69 * \star \star$ & & \\
\hline $\begin{array}{l}\text { Hyphal length } \\
\text { density }\end{array}$ & $36^{\star \star \star}$ & & $147 * \star \star$ & & $163^{\star \star \star}$ & & \\
\hline $\begin{array}{l}\text { Mycorrhizal growth } \\
\text { response }\end{array}$ & $3.3^{\star \star}$ & & $188^{\star \star \star}$ & & $2.3^{*}$ & & \\
\hline $\begin{array}{l}\text { Mycorrhizal P } \\
\text { response }\end{array}$ & $5.8^{\star \star}$ & & $286^{\star \star \star}$ & & $2.0 *$ & & \\
\hline $\begin{array}{l}\text { Absolute mycorrhizal } \\
\text { growth } \\
\text { responsiveness }\end{array}$ & $3.4^{\star \star}$ & & $175^{\star \star \star}$ & & $2.0 *$ & & \\
\hline $\begin{array}{l}\text { Absolute mycorrhizal } \\
\text { P responsiveness }\end{array}$ & $7.1^{\star \star \star \star}$ & & $238^{\star \star \star \star}$ & & $2.9 * \star$ & & \\
\hline
\end{tabular}

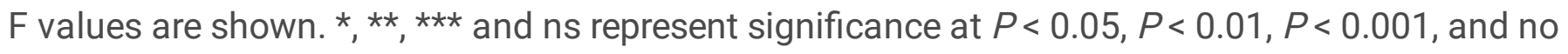
significance, respectively, after Benjamini-Hochberg correction. 
Table 2 Correlations between shoot biomass and root traits at different $P$ application levels $\left(P_{0}, P_{50}\right.$, $\left.P_{300}\right)$, when plants were inoculated without and with $\operatorname{AMF}(n=8)$.

\begin{tabular}{|c|c|c|c|c|c|c|}
\hline & $\mathrm{P}_{0}$ & & $P_{50}$ & & $P_{300}$ & \\
\hline & -AMF & + AMF & -AMF & $+\mathrm{AMF}$ & $-A M F$ & $+\mathrm{AMF}$ \\
\hline Root biomass & $0.85^{\star *}$ & $0.71 *$ & $0.71 *$ & $0.79 *$ & 0.25 & 0.50 \\
\hline Root shoot ratio & $-0.92^{\star \star}$ & -0.12 & $-0.77 *$ & 0.16 & -0.27 & 0.14 \\
\hline Root length & 0.27 & 0.11 & 0.51 & 0.49 & 0.54 & 0.43 \\
\hline Specific root length & 0.42 & 0.35 & 0.53 & 0.45 & 0.62 & 0.37 \\
\hline Proportion of fine root length & 0.00 & $-0.76 *$ & -0.32 & -0.12 & -0.02 & -0.05 \\
\hline Mean root diameter & 0.66 & 0.46 & 0.46 & $0.91^{* *}$ & -0.14 & 0.30 \\
\hline Root tissue density & 0.26 & 0.69 & 0.20 & -0.47 & -0.69 & 0.04 \\
\hline $\begin{array}{l}\text { Phosphatase activity of rhizosphere } \\
\text { soil }\end{array}$ & 0.08 & -0.39 & -0.36 & -0.04 & $0.74^{*}$ & 0.25 \\
\hline $\begin{array}{l}\text { Phosphatase activity on root } \\
\text { surface }\end{array}$ & $0.77 *$ & -0.07 & 0.66 & 0.27 & -0.14 & -0.14 \\
\hline Mycorrhizal colonization & & -0.27 & & 0.60 & & 0.38 \\
\hline Hyphal length density & & 0.19 & & 0.39 & & 0.40 \\
\hline
\end{tabular}

$r$ values are presented. Values in bold indicate significant correlations, * and ** represent significant correlations at $P<0.05$ and $P<0.01$, respectively (Pearson coefficient at $P<0.05$ ).

Table 3 Correlations between shoot $P$ content and root traits at different $P$ application levels $\left(P_{0}, P_{50}\right.$, $\left.P_{300}\right)$, when plants were inoculated without and with $\operatorname{AMF}(n=8)$. 


\begin{tabular}{|llllllll|}
\hline & $P_{0}$ & & $P_{50}$ & & $P_{300}$ & \\
\hline & $-A M F$ & +AMF & - AMF & +AMF & -AMF & +AMF \\
\hline Root biomass & $\mathbf{0 . 7 9 *}$ & 0.55 & 0.46 & $\mathbf{0 . 7 6 *}$ & 0.04 & 0.32 \\
\hline Root shoot ratio & $-\mathbf{0 . 7 7 *}$ & -0.14 & $-\mathbf{0 . 7 4 *}$ & 0.16 & -0.04 & -0.01 \\
\hline Root length & -0.077 & 0.12 & 0.38 & 0.48 & 0.32 & 0.13 \\
\hline Specific root length & 0.10 & 0.29 & 0.32 & 0.41 & 0.15 & 0.13 \\
\hline Proportion of fine-root length & -0.22 & -0.59 & -0.05 & -0.01 & 0.36 & -0.05 \\
\hline Mean root diameter & 0.67 & 0.39 & 0.05 & $\mathbf{0 . 8 7 * *}$ & -0.67 & 0.27 \\
\hline Root tissue density & 0.53 & 0.47 & 0.20 & -0.47 & 0.16 & 0.13 \\
\hline Phosphatase activity of rhizosphere soil & -0.20 & -0.33 & -0.27 & -0.07 & 0.10 & 0.03 \\
\hline Phosphatase activity on root surface & $\mathbf{0 . 8 0 *}$ & -0.06 & 0.42 & 0.29 & -0.14 & -0.33 \\
\hline Mycorrhizal colonization & & -0.64 & & 0.62 & & 0.22 \\
\hline Hyphal length density & & 0.47 & & 0.51 & & 0.09 \\
\hline
\end{tabular}

$r$ values are presented. Values in bold indicate significant correlations, * and ** represent significant correlations at $P<0.05$ and $P<0.01$, respectively (Pearson coefficient at $P<0.05$ ).

\section{Figures}



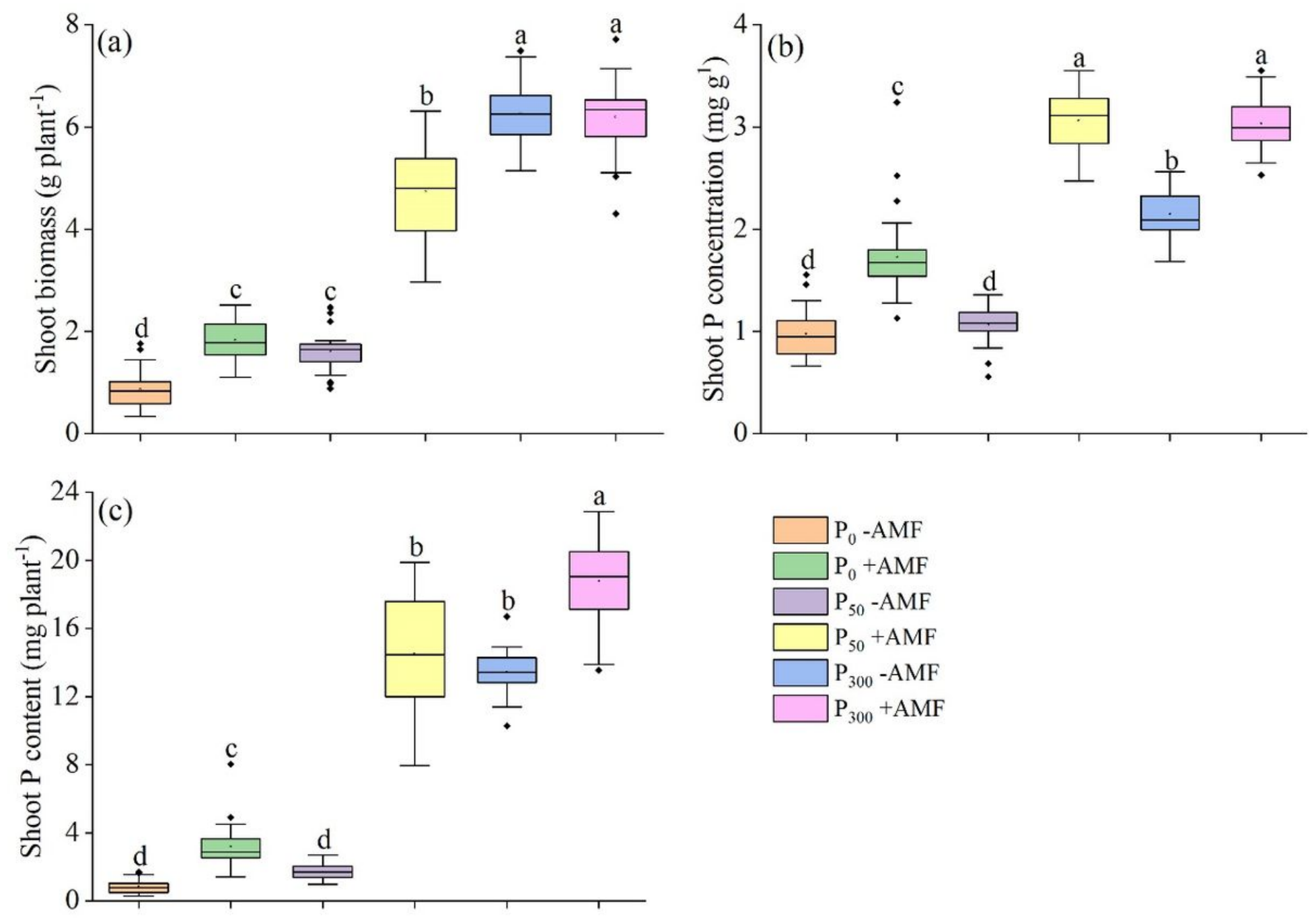

Figure 1

Variation in shoot biomass (a), shoot $\mathrm{P}$ concentration (b) and shoot $\mathrm{P}$ content (c) with and without arbuscular mycorrhizal fungi (AMF) at three P levels (P0, P50, and P300). Different letters indicates significant differences at $\mathrm{P}<0.05$ among six treatments. 

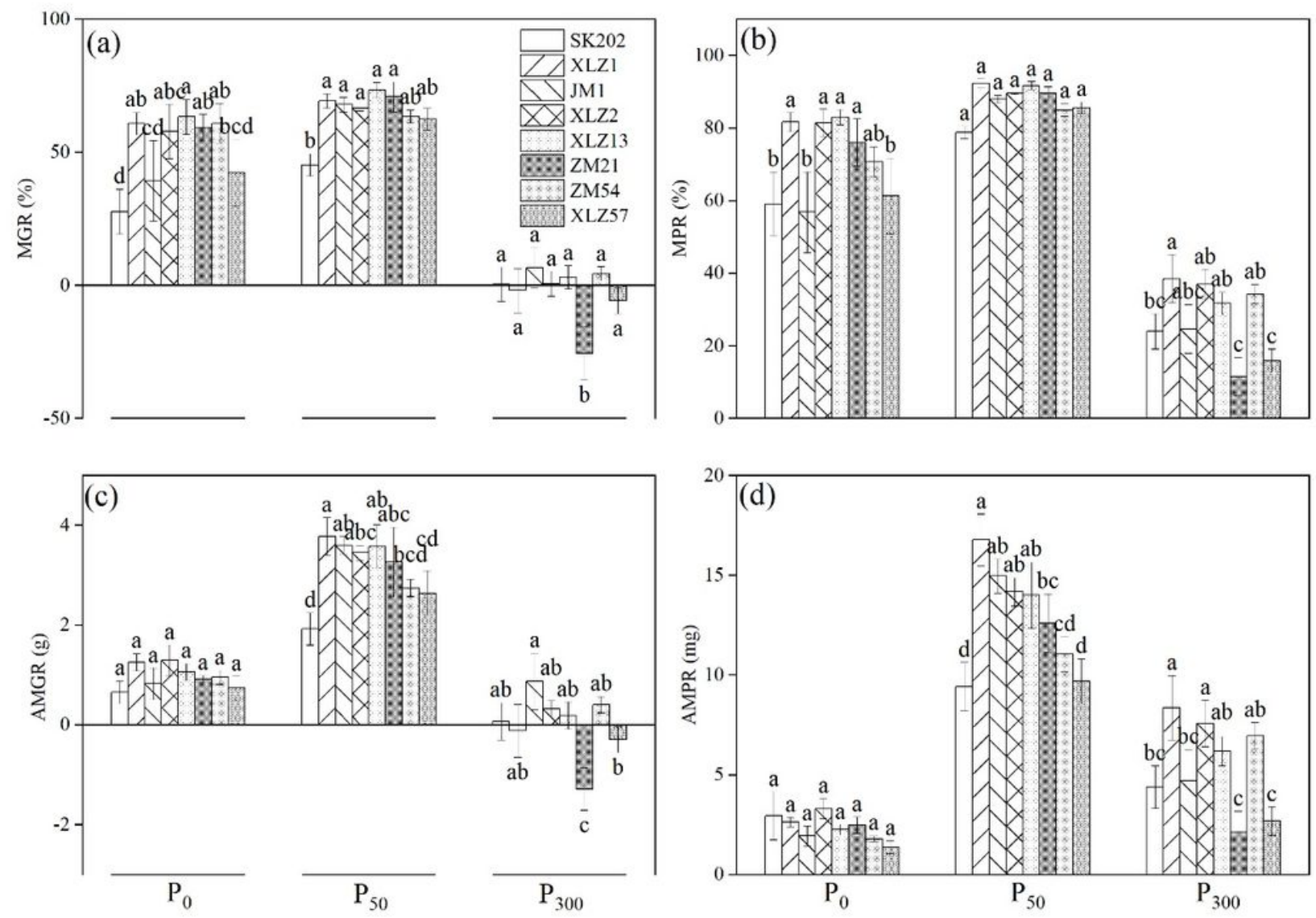

Figure 2

Mycorrhiza-induced changes in relative $(a, b)$ and absolute $(c, d)$ shoot biomass $(a, c)$ and shoot $P$ content (b, d), for cotton varieties as a function of P application (P0, P50, P300). Different letters indicate significant differences at $\mathrm{P}<0.05$ among varieties at a given $\mathrm{P}$ level.
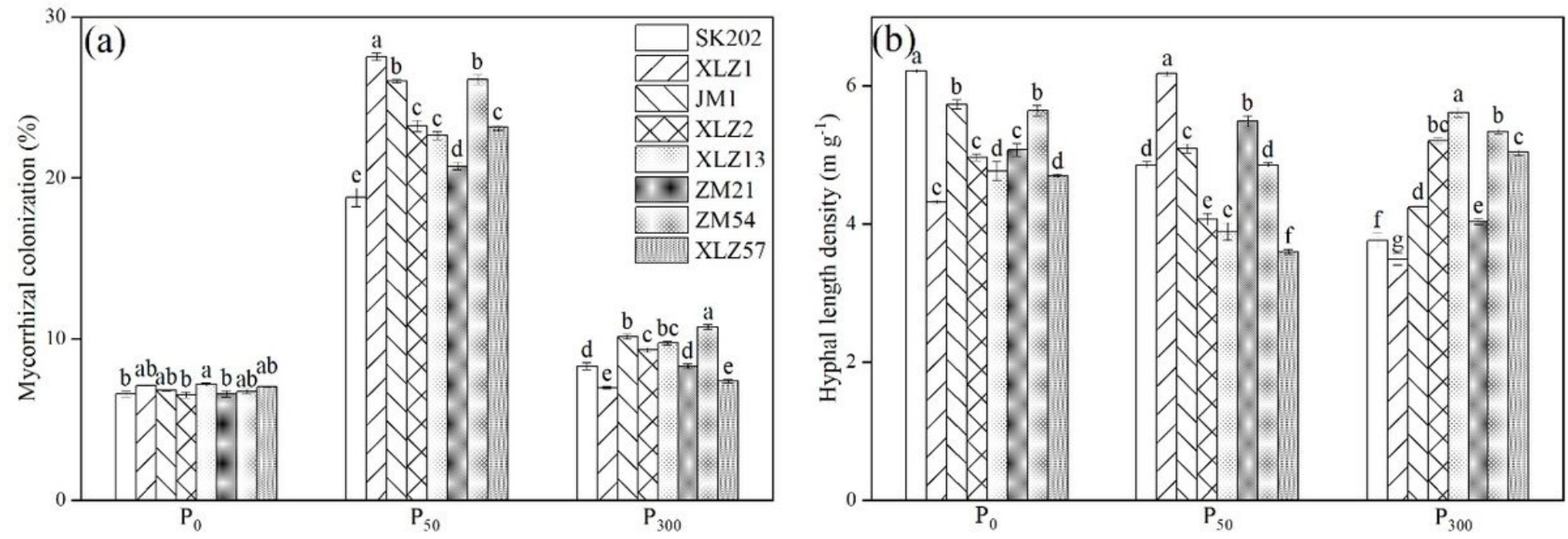

Figure 3 
Mycorrhizal traits (mycorrhizal colonization, a; hyphal length density, b) as influenced by $\mathrm{P}$ application (P0, P50, P300) and cotton varieties (SK202, XLZ1, JM1, XLZ2, XLZ13, ZM21, ZM54 and XLZ57).

Different letters indicate significant differences at $\mathrm{P}<0.05$ among varieties at a given $\mathrm{P}$ level.
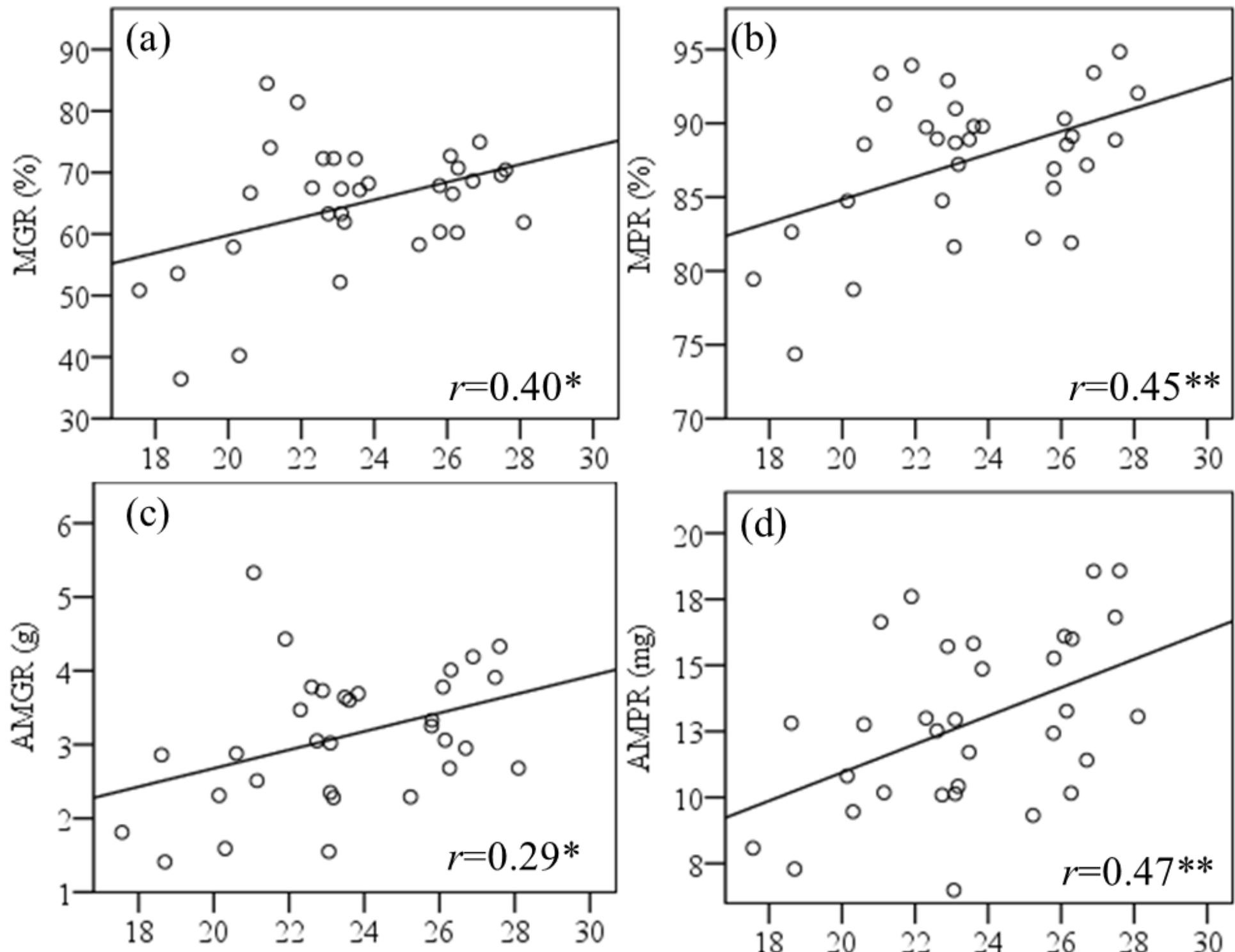

Mycorrhizal colonization (\%)

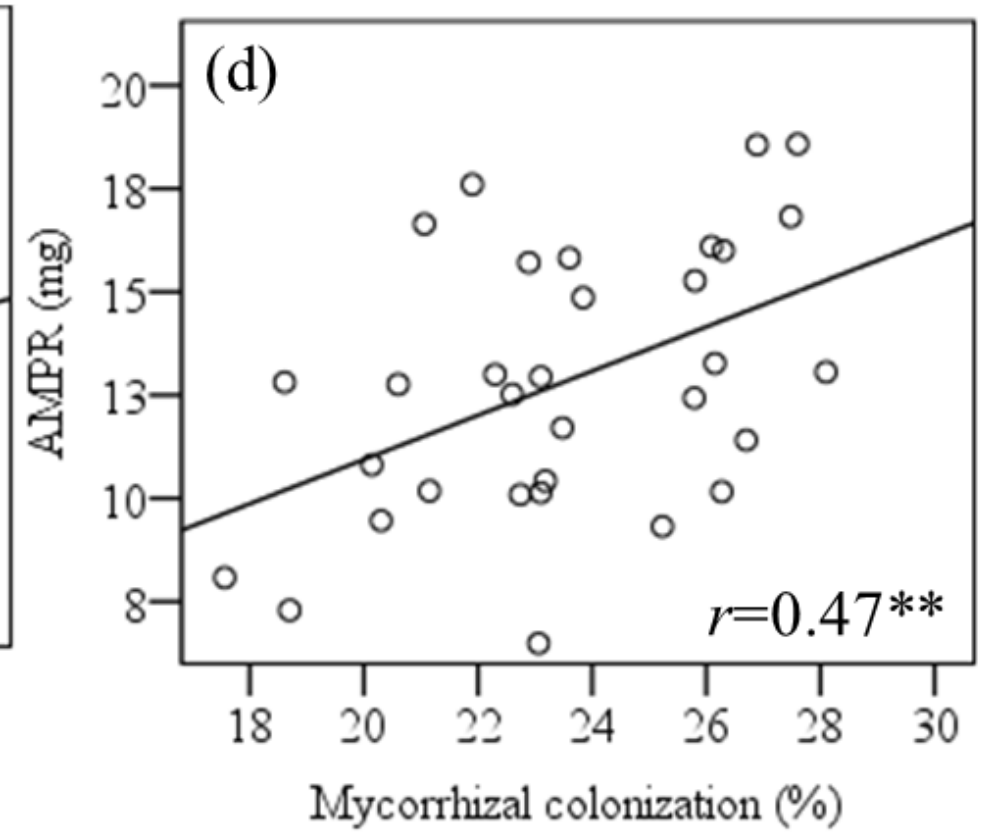

Figure 4

Correlation between mycorrhizal colonization of cotton varieties and relative or absolute mycorrhizal responses at $\mathrm{P} 50$. $\mathrm{r}$ values are presented. * and ** represent significant correlations at $\mathrm{P}<0.05$ and $\mathrm{P}<$ 0.01 , respectively (Pearson coefficient at $P<0.05$ ).

\section{Supplementary Files}

This is a list of supplementary files associated with this preprint. Click to download. 
- 4.supportingmaterials0508.docx

Page 25/25 